\section{Ethnographic Studies of Bakor Stone Monolith and Their Implication to Tourism Development}

\author{
Ajoma Simon Okwoche ${ }^{1}$, Emeka Emmanuel Okonkwo ${ }^{2}$, Tawo Alfred Oyong ${ }^{3}$ \\ ${ }^{1}$ Department of Archaeology and Tourism, Faculty of Art, University of Nigeria, Enugu, Nigeria \\ 2Department of Archaeology and Tourism, Faculty of Art, University of Nigeria, Enugu, Nigeria \\ ${ }^{3}$ Department of Archaeology and Tourism, Faculty of Art, University of Nigeria, Enugu, Nigeria \\ Email: jomosinee@gmail.com, emeka.okonkwo@unn.edu.ng, tawoalfred@gmail.com
}

\begin{abstract}
:
Monoliths in the Cross River State of Nigerian are found in a circular form, they are commonly known as Bakor or Ikom monoliths, because of the universality in conceptualisation and the configuration of the stones, they are sometimes referred to in this research as stone circles. Bakor speaking communities hold a large number of magnificent stone carvings called Bakor monoliths which exhibit a high level of artistic, qualities, and creative awareness by the ancient civilisation that creates them. The study is aimed at examining monoliths in Bakor LGA, to ascertain the socio-cultural and religious beliefs associated with these monoliths and their contributions to tourism development in Cross River State. A mixed-method of qualitative and quantitative research was employed. The result reveals that Cross River State monoliths have the potentials of attracting tourists, and are valued by host communities. However, the monoliths are under human and natural threats. The paper advocates that if Bakor monoliths are developed for cultural tourism, it will create job opportunities, improve the living standard of the host community, generate revenue, and guaranty their preservation, among others.
\end{abstract}

Keywords:

bakor monoliths; nsibidi sign; cultural tourism; development

\section{Introduction}

Through their various roles to tourists in the context of cultural tourism, monoliths have a lot to contribute to the national economy. A typical tourist (foreigner) is always encouraged to tour or visit a given tourist destination based on the availability of information on the proposing destination. This is due to the fact that tourism cannot exist without tourists moving across or within national borders. It is important to note at this point that travel is an essential component of any tourism, as the essence of tourism is the moment.

Stone circles can also be found in Nigeria's Cross River State. They are commonly referred to as monoliths by the people of the state, but due to the universality in conceptualisation and stone configuration, these are referred to as stone circles in this project report. The tourism industry in Cross River State reached a tipping point in the year 2000, when former Governor of Cross River State Mr. Donald Duke's administration recognized and promoted tourism as one of the state's economic pillars. Bakor-speaking languages are home to a large number of magnificent stone carvings known as Ikom (Bakor) Monoliths, which demonstrate a high level of artistic qualities and create awareness of the ancient civilization that created them was aware of this. The available literature and discussion on the Ikom monoliths provide important anthropological insights, but there is no in-depth analysis of the stone carvings. An earlier study by Eyo (1986) claimed that the Ikom monoliths dated back to 200Ad. 


\section{Lakhomi Journal: Scientific Journal of Culture \\ ISSN: 2774-311X (Online), 2774-4728 (Print)}

Vol. 2, No. 4, December 2021, Page: 171-187

Email: lakhomijournal@gmail.com

The number of these magnificent stone carvings ranges between 400 and 450, and they are spread across several villages in the Bakor's communities of Cross River North (Acholonu, 2005); read on for more information on the villages where these monoliths are located. The stone carvings are arranged in 30 circles, with specific measurements ranging between 3 and 5 feet (Vesperini, 2007). He is in them, they are carved into phallus shapes and creatively decorated with carvings of geometric and stylized human features, as well as various facial marks (UNESCO 2007 as cited in Clement . 2014).

\section{Scope of the Study}

The study covers Ikom and Ogoja Local Government Area of Cross River State, otherwise known as Bakor communities, Stone circle are found in Ikom and Ogoja Local Government areas of the state. The area is located between longitude $8{ }^{\prime} 300 \mathrm{E}$ and $8{ }^{\prime} 400 \mathrm{E}$ and latitude $6 \cdot 00 \mathrm{~N}$ and $8.200 \mathrm{~N}$. The stone is commonly called by the names of the communities' Emangabe monoliths, Nkarasa monoliths, and Alok monoliths, etc. They are sometimes called the "Bakor" monoliths because all the Bakor communities where the carved stones are found are the Bakor speaking communities. The Bakors are found in Ikom and Ogoja Local Government Areas. The stone is also called "Akwanshi". By few individuals means "dead people". The interview conducted pointed out that the people of Bakors are from Bantus or belong to the Bantus group of Negro. And the group can also be found in other parts of the country such as Tiv, Idoma, Igala, and Nupe. All these groups speak a related dialect of the Benue Congo Subfamily. The people of the study area are referred to as Ejagham, the Ejagham includes. Ayuk cited in Chris (2013) Ejagham was derived from the lake ifagham. The name was coined from Ejak, which mean let clap this was probably said by the first inhabitant of Ejagham land when their first saw the extraordinary piece of water, whilst Bakor language has been identified by linguists as a true Bantu language. These also because if prefixes alternate between singular and plural forms, a characteristic shared by all Bantu language.

\section{Research Method}

\subsection{Data Collection}

The instrument used in collecting data for this study includes ethnography, fieldwork, interview, observation, documentary materials time horizon. The purposes were to examine the people's perspectives and to get varied information on their culture in the context of tourism through monoliths using different methods in other to help analyze the data properly.

\subsection{Data Presentation}

Data for historical research are obtained from two main sources which include primary and secondary sources. Whenever the primary sources are there to use the secondary sources could be considered a serious error for the obvious reason that secondary sources are usually susceptible to distortion and hence be as authentic as the primary sources (Nwogu 1991). In evaluating the data two forms of criticism are applied.

Data will be presented and analyzed based on the finding from the field survey. From the study, does Ogoja and Ikom have stone carving (monoliths), stones carving are found in the two local government Areas of Cross River State, the stone are commonly called by names of the communities; Esham monoliths, Nkarasi monoliths Alok Monoliths, etc. they are sometimes called the Bakor monoliths because all the communities where the carved stones are found are the Bakor speaking communities. 
The monoliths are found in twelve (12) villages, they include Alok, Emangabe, Ntolshi, Edankono, Nlun, Agba, Nkirigom, Ntol, Njeemitop, Nnam, Nselle, and Nta. However, my study will be limited to four selected sites they including Alok, Emangabe, Esham, and Nkirigom because of the cluster of the stones in these sites.

\section{Result and Discussion}

\subsection{Oral History of the Monoliths in Ogoja}

Informant (Chief Molang) give a brief description of the stones by Ekajuk people of how the stones can't be easily seen by visitor unless scarifies are been made to with up wine, native kola, and other items to appease the gods before the stones will be visible to the visitor, he when further to say Ekajuk stones grow itself, Ekajuk people have said to migrated from South Africa and speak the same language as Bikwo, Akanpa, and Cameroon. For the people of Ekajuk monoliths are referred to as Ataptal, meaning long stones they believe that before the stones are been carved their ancestors will carry out spiritual work by smoothing the stones and cut their faces on the stones with iron, that is the supernatural being usually perform the art work before the human will use their fingers to trace the cast made by the spiritual beings.

Oral History of the Monoliths in Ikom

According to Mr. Charles Awan in an interview conducted reveal that the stones were originally scatter in different location within the communities until they realize that the stones were missing gradually and also when communities was also aware of the importance of the stone to the state and communities at this time the rate of stealing was very high make the communities call for government intervention the National Commission for Museums and Monuments (NCMM) came and built a museum and a security house and which the carved stones were brought into the museums in a standing and a circular forms. The techniques for carving are engraved line of surface decoration with depression for beard and protrusion to form the navel. The carvers are called monkom in Nnam dialect.

\subsection{Current Sighting of the Monoliths of Ogoja and Ikom}

Currently, the monoliths are all over the eight clans of Bakor, includes are the total number of monoliths per site, Alok has 33, Emangabe has 17, Nkarasi 17, Ntolish 16, Edankono 8, Nlun 14, Agba 26, Nkirigom 27, Ntol 30, Nselle 7, Nebrokpa 10 all in a semi-circle and circular form of which some are standing others are laying. Four sites were selected because of accessibility, proximity, and information that will be generated. But all the four sites have one common name called Alok open-air museums; the three sites include Alok, Emangabe, Nkirigom and Esham. Considering the size and types of rock used in their production show that the monument cannot disintegrate easily, except by environmental change. This was the reason we still have it till have some of them in their different sites. The carvings depend on the size, shape, and skill of the carvers. The carved features are observed to appear on the front facial, breast, and novel. These are prominent decorations found in the monoliths. Nsibidi inscription found on the stones is a type of language spoken by body movement and writing on the air and ground by the people till date. Some sites are contiguous while other is far from others; some are forested while others are found close to human habitation. The forested sites are Nkirigom, Agba, Ntol, Nta, Njemitop, Ntolish and Edankono. The implication is that the stones are subjected to bush burning and vandalisation. 


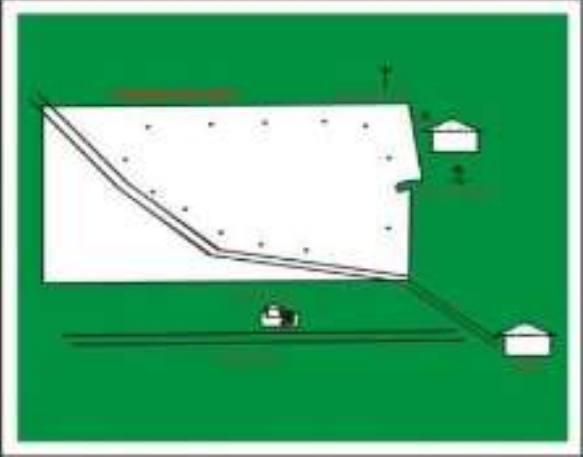

Figure 1. Site Plan for Emangabe museums

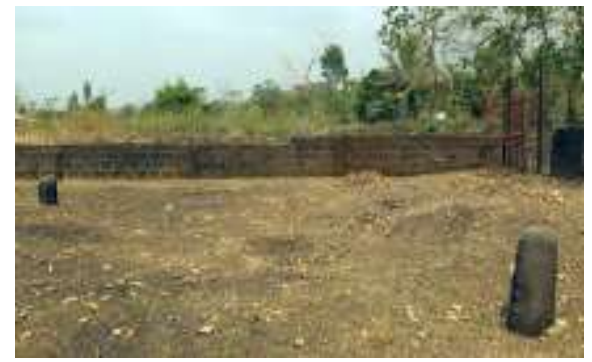

Figure 2. Emangabe Open-air museum

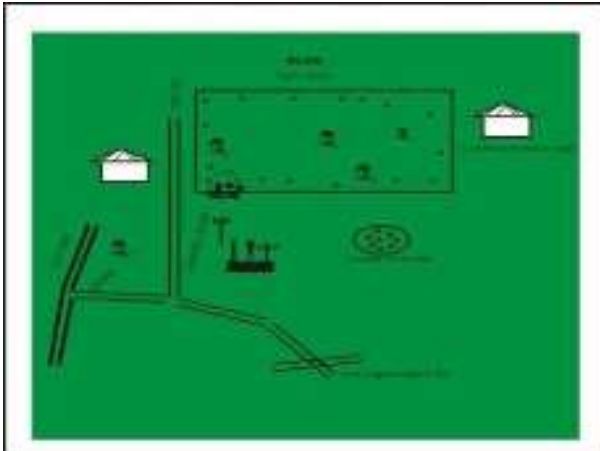

Figure 3. Site Plan for Alok museum

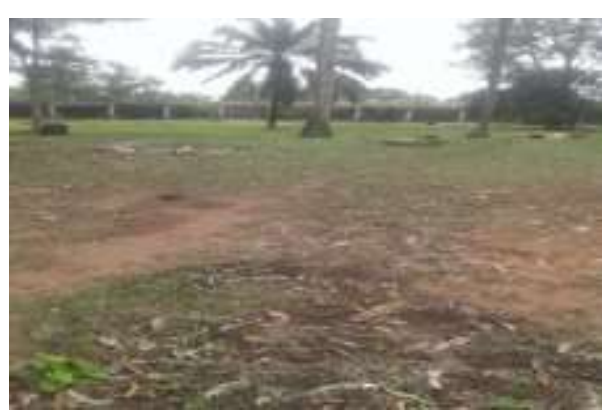

Figure 4. Alok Open Air Museum 


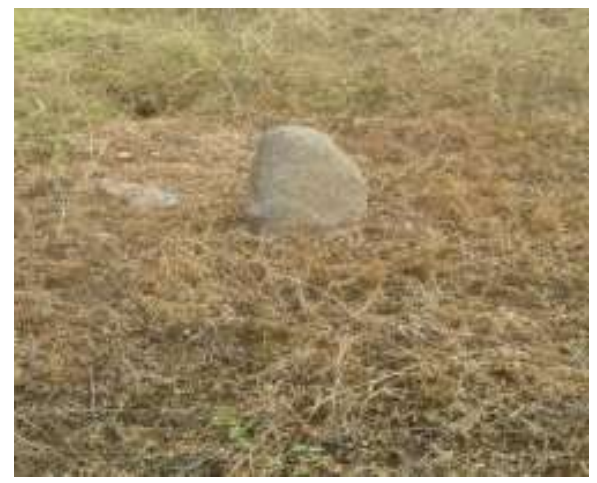

Figure 5. The Paramount Stone Monolith

It is a paramount stone where rituals are been carried out on stone to appease the ancestor before the new yam festivals. The stone has a triangular sign on it, there are four triangle squares, and the two triangular squares are the former despite the four age groups in the community. The two triangle squares represent the two groups of warriors who carry elephant tusk Arobe and Nkpanyang It has a latitude of $06^{\circ} 19^{\prime}$ '42.3' and longitude $008^{\circ}$ ' 39 07. 9' with a height of $43 \mathrm{~cm}$ and $117 \mathrm{~m}$ as elevation, a distance of 5.57 .

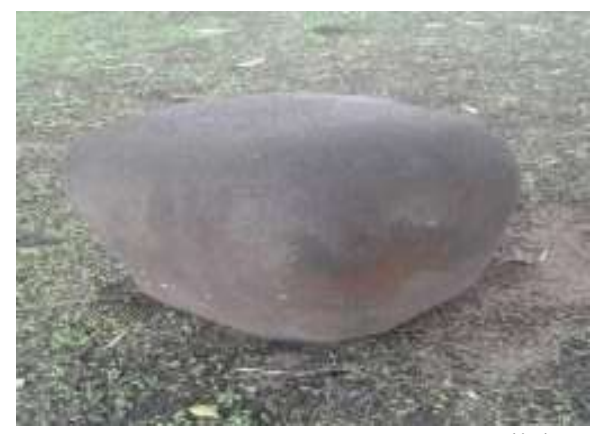

Figure 6. Peace stone monolith

The inscription of the stone shows a peace sign. This is used when two communities fight and decide to make peace after a tribal war. It has a latitude of $06^{\circ}$ ' $1943.1^{\prime}$ and longitude $008^{\circ}$ '39 07. 7' with the height of $60 \mathrm{~cm}$ and $117 \mathrm{~m}$ as elevation, a distance of 5.60 .

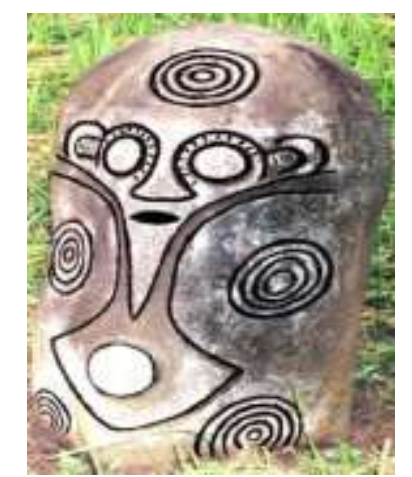

Figure 7. Akpanyan (a talking stone)

It has a symbol of power that most chiefs held in their today and is called Ekan by the community. 


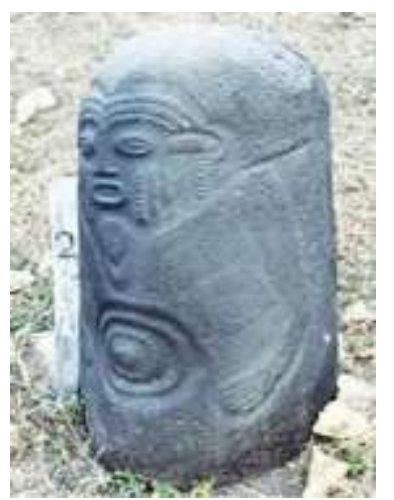

Figure 8. Stone monolith representing a visionary

The stone has nsibidi sign meaning a woman who is mourning because she lose her husband. It has latitude of $06^{\circ}$ ' 19 42.1' and longitude $008^{0}$ ' 39 108. 0 " with height of $85 \mathrm{~cm}$ and $123 \mathrm{~m}$ as elevation, distance of 6.73 .

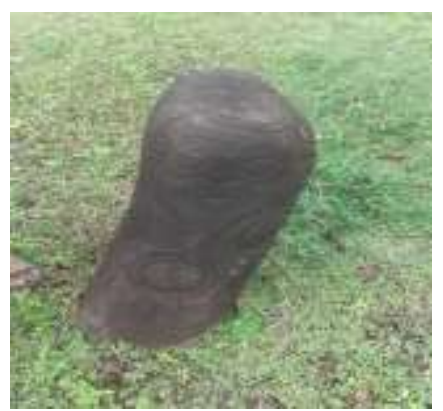

Figure 9. Couple Stone Monolith.

The stone has an nsibidi sign with a concentric circle, a man and woman met together and married, meaning couple in nsibidi writing. It has clockwise and anti-clockwise. It has a latitude of $06^{0}$ ' 1942.1 and longitude $008^{0}$ ' 39 08. 1' with a height of $84 \mathrm{~cm}$ and $123 \mathrm{~m}$ as elevation, the distance of 5.6.
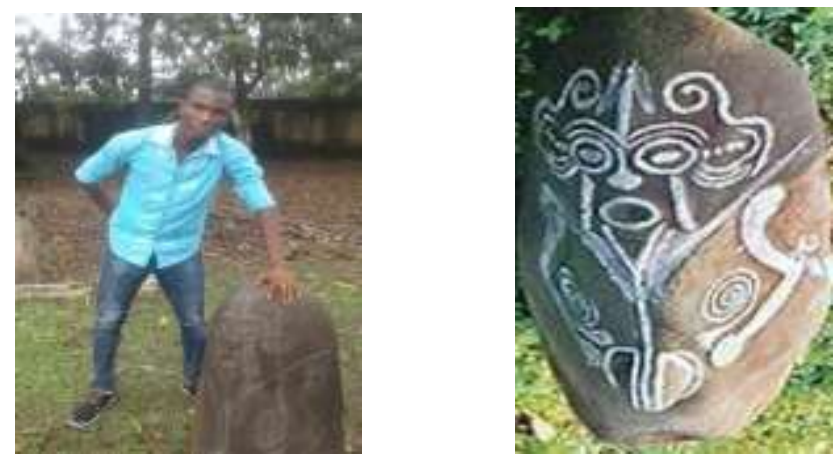

Figure 10. Researcher with fertility stone monolith.

It has the sign of fertility, It stands for Agbosis the name of the first Nnam woman who first starts having children. It also has two sets of concentric circles, clockwise and anticlockwise. The clockwise circle depicts male while the anticlockwise depict female the concentric circles represent a union of male and female in marriage. So many tourists came and make a sincere wish and it was granted unto them by the stone. It has a latitude of $06^{\circ} 19^{\prime}$ '42.6' and longitude $008^{0} 39^{\prime} 07.4$ with a height of $90 \mathrm{~cm}$, elevation of $115 \mathrm{~m}$ and has a distance of $8.55 \mathrm{~cm}$. 


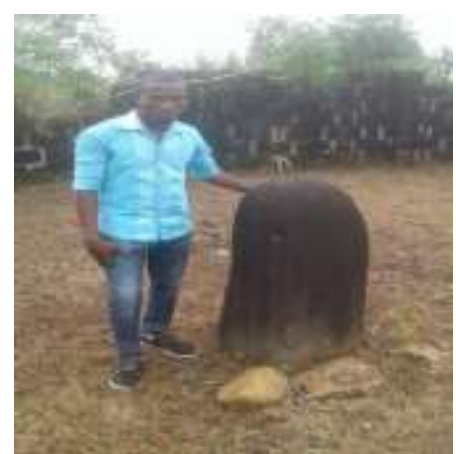

Figure 11. The researcher with a stone monolith (Ntulenmang).

It represents the Ntulenmang. The first Ntulenmang was mgbe Abang Mbua, the Ntulenmang is the current paramount ruler of Ikom Local Government Area. It has a latitude of $06^{0} 19^{\prime} 41.5^{\prime}$ and longitude $008^{\circ} 39^{\prime} 07.2$ with a height of $120 \mathrm{~cm}$, an elevation of 120 and has a distance of 5.54 .

The arrangement of stone in Emangebe stone circles is of significant importance to engineering and astronomers it shows that the builders were skillful in craftsmanship in the way the stone was arranged to give the circular shape as shown above. This somehow shows or supports the assumption of professor "Thom (1978) megalithic remain in Britain and Britany Clerando" that stone circles were used for calendrical reckoning, and the uses of the stones for counting market have had some level of cosmological consciousness and well skillful in astronomic and geometry.

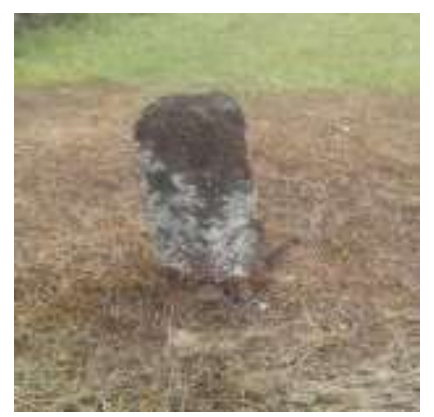

Figure 12. Stone monolith representing warriors

Warriors are always carved with volcanic rock, they are defaced with whitish color and lose surface inscription. It has a latitude of $06^{\circ} 19^{\prime}$ '41.6' and longitude $008^{0} 39^{\prime}$ ' 08.1 with a height of $102 \mathrm{~cm}$, elevation 123 and has a distance of 5.34. And the second one has a latitude of $06^{\circ} 19^{\prime}$ $42.1^{\prime}$ and longitude $008^{\circ} 39^{\prime} 07.1$ with a height of $85 \mathrm{~cm}$, elevation 118 and has a distance of 8.57 .

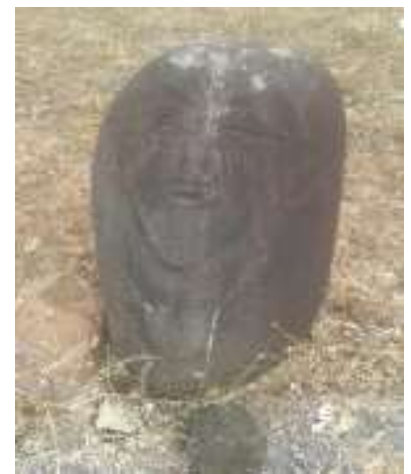

Figure 13. The stone monolith represents the female vision of Ekpe secret society 
It always comes out in the night. It is believed that any man who sees them will die. It has a latitude of $06^{\circ} 19^{\prime} 41.8^{\prime}$ and longitude $008^{\circ} 39^{\prime} 07.0$ with a height of $80 \mathrm{~cm}$, elevation $120 \mathrm{~m}$ and has a distance of 8.97.

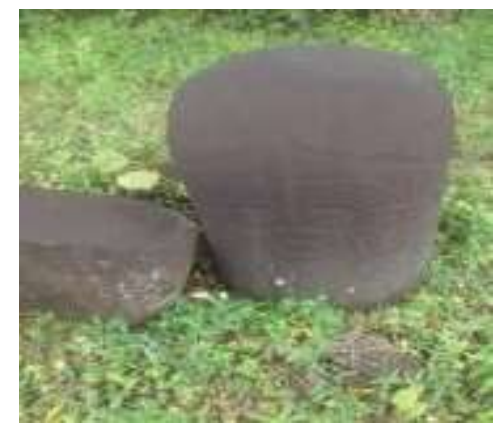

Figure 14. Stone monolith representing a visionary.

It has a two-star inscription which means, the man that has the ability to see into the future, a visionary is one who can envision the future. Divination can be seen as a systematic method with which to organize what appear to be disjointed, random facets of existence such that they provide insight into a problem at hand. For some groups, this can involve the supernatural. It has a latitude of $06^{\circ} 19^{\prime} 41.2^{\prime}$ and longitude $008^{\circ} 39^{\prime} 07.3$ with a height of $80 \mathrm{~cm}$, the elevation of $125 \mathrm{~m}$ and has a distance of 8.54 .

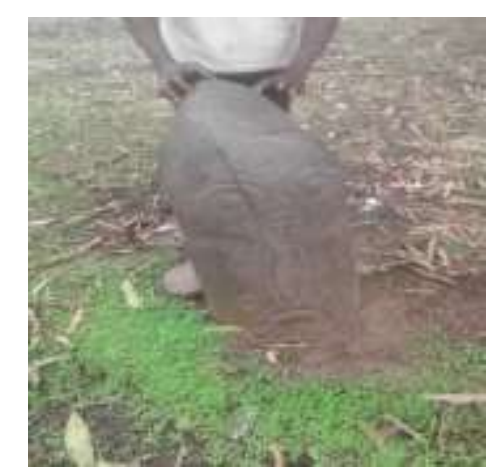

Figure 15. Stone monolith representing a king stone

It has seven crowns, he is a brave man with long bears, who have to lead the community in a tribal war, he has chieftaincy title, he is the first king of Nlun, Mgbe Aba-Mbeny. The man has conquered seven times in the tribal war and so he was given a chieftaincy. Deteriorating with major crack, Its latitude is $06^{0} 18^{\prime} 45.4^{\prime}$ and longitude $008^{0} 39^{\prime} 18.0^{\prime}$, the height of $69 \mathrm{~cm}$, the elevation of $108 \mathrm{~m}$, and $37.7 \mathrm{ft}$ of distance apart.
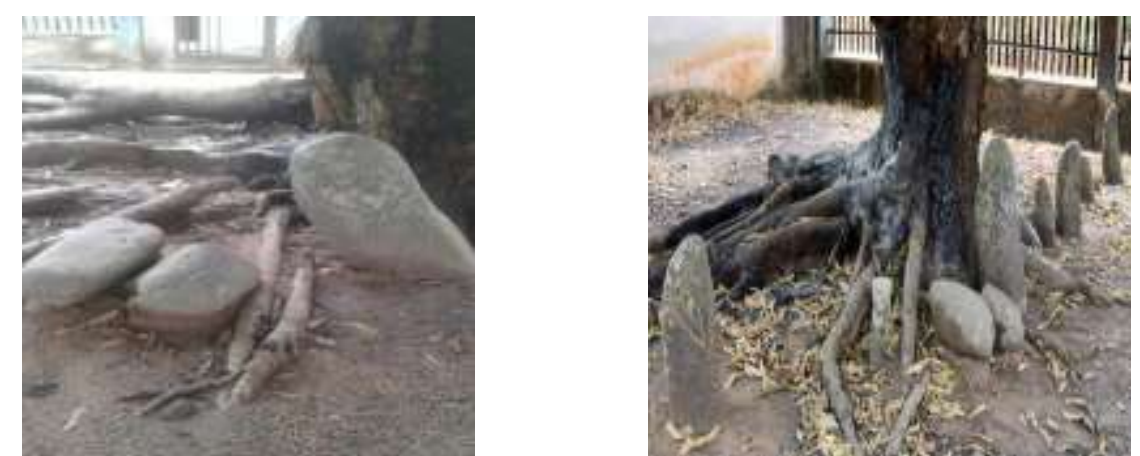

Figure 16. Stone monolith representing children. 
Children gather and play around the stone scarifies are made to the stone before the celebration of the new yam festival. It is used by tourism bureaux as their logo. It has clockwise and anti-clockwise, the stone is painted with green, red, blue, white, and yellow it has a latitude of $06^{0} 19^{\prime} 107^{\prime}$ and longitude $008^{0} 38^{\prime} 53.4^{\prime}$, it is $94 \mathrm{~cm}$ in height, $141 \mathrm{~m}$ in elevation, and has a distance of $1.8 \mathrm{ft}$ apart.
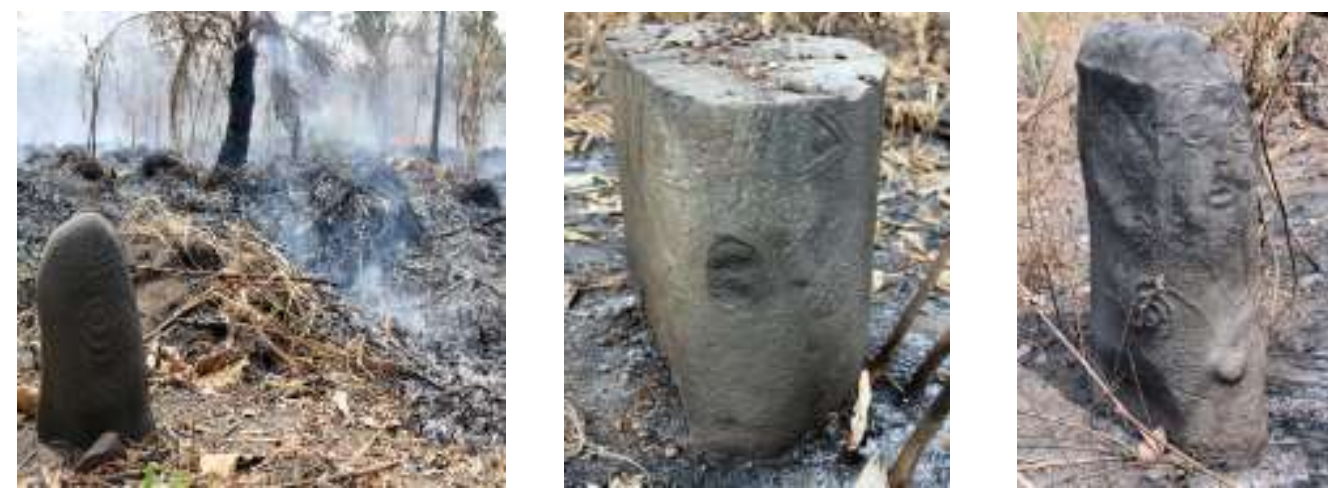

Figure 17. All of the stone monoliths are under the threat of bush burning

Silk cotton tree fell as a result of burn-in Nnam Open Air Museum with monolith around it
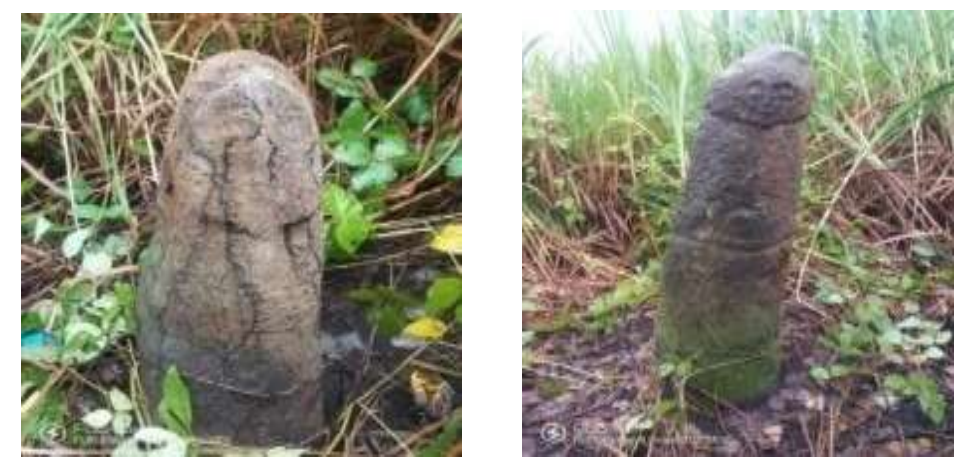

Figure 18. Stone monolith presenting mother (Monajuk).

Representing the mother of the clan who the other linage comes, they are of the belief that the stone represents who gave birth to them.

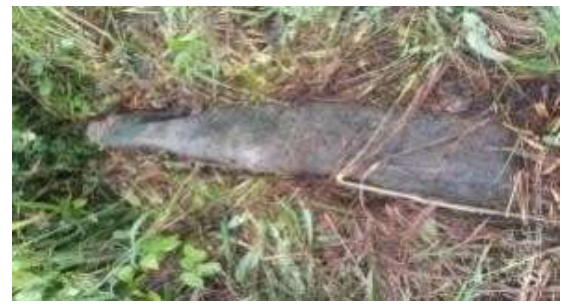

Figure 19. Stone monolith representing security (Nkumm)

It protects the people of the community against their enemy who will invade their land for tribal war. 


\subsection{Challenges Facing the Management Practices of the Monoliths}

According to Ivor, M., and Abu E. (2015), in his simple title "cross River monoliths: In critical danger of total destruction," the remaining stones of Cross River are in critical danger of total destruction, either due to five caused by local communities or theft.

That is to say, the Cross River state monoliths are lacking in terms of management and government involvement, as well as stakeholders, who are also communities within or around the monoliths. The community's difficulties in farming around the perimeters of its wall, where slash and burning methods were used. Also, the gardeners who looked after the place were burning the grass rather than cutting it; This has also resulted in the monoliths' continuous degeneration. It was ascertained that there is evidence of burning fire inside the museums as a consequence of the mango leaves that slump on the ground was by the museum's attendances that have a negative impact on the stones by breaking, also the majority of the stones have indeed been neglected in the vegetation with no for it, the indigenous farm around the perimeter walls of the fens, the museum attendance maintaining a perhaps the presence of the monoliths in the locations is limited due to theft and fraud by cultural smugglers. Heat abrasion, capillary rising, and massive waterways have all had an impact on the stones. As a result, seep through the surface, causing the surface to slowly erode and evacuate delicate exterior fragments. Some of the monoliths are lying on the ground, possibly due to moisture or weak soil, and others due to fallen branches. Colored phytoplankton is commonly found on the surfaces of monoliths, including but not limited to Nkirigom, Alok, and Emangabe; In fact, almost all of the locations have a defaces relationship with the algae. Fertilizers and grasslands grow all over them during the rainy months. It is most commonly seen in volcanic debris, which is used to sculpt warriors like Emangabe and Alok. In fact, almost all of the sites have a defaced relationship with the algae. During the rainfall, ferm and vegetation growth across them. It is mostly observed in rock formations, which are used in sculpting warriors, as seen at the Emangabe and Alok sites. any of the initial surfaces of the stones have now been lost due to surface abrasion and erosion caused by wind, rain splash, and runoff. Slight and major cracks, ring crack propagation, flakes, and fracture surface marks have been identified as cracks (Chris 2013). Human activities cause the monoliths to be distorted, altered, and lost at a rapid rate. Since the year 2000, the occurrence of bushfires is said to have increased in almost all locations. Mosses, lichens, and liverwort are among the microgrowths discovered in the sites. The bryophytes encountered in the open air are Hyophila involuta pottiaceac, and the lichens are Parmelia Spp. Parmeliacaec. Black and whitish stain bleaching caustics are usually observed in all locations. It is important to note that the monoliths themselves are an attraction that lures other variables as a result of bush burning.

The major issues currently facing the memorial plaque in the locations are insufficient protection and preservation of historical sites. The locations have the right to be preserved and protected, as well as to receive attention and maintenance from stakeholders. In most real-world situations, however, the opposite is true. For example, the monoliths in Nkirigom sites, as well as a few from Alok and Emangabe, are vandalized by whitish-colored and major cracks, and there are no sanitary amenities for visitors. Which, in turn, has diminished their worth and implications?

According to Okpoko and Ezeadichie (2002), The sustainability and promotion of designated excavation, ethnographic, and sacred historical sites as historic excellence centers, backed up by the provision of suitable facilities and equipment within these sites to make them enticing to visitors, are critical. 
* Infrastructure that is insufficient. The original open space is badly controlled and monitored for tourism activities, and the state of the roadways, particularly in the enclosure of the settlements, needs an overhaul because the entrance to many of the sites is challenging during the rainfall.

* There is a public admiration deficit. The vast majority of people in Bakor and Cross River State do not value their cultural sites. The overwhelming bulk of intellectual elite who are well mindful and value these historical monuments do not bother to visit them. This lack of public respect and admiration poses significant challenges to the monuments' existence, sustainability, and continuity. As a result, conservation and protection measures should be implemented to protect it from damage and to be involved in the management of the locations for tourist activities. The vast bulk of the monoliths have been harmed as a result of human activity and the ecosystem. The government must hire more people to help with the preservation and protection of the monoliths, which are our historic and cultural assets. As a result, the success of greener cultural tourism survival and prosperity is dependent on the preservation of a healthy and appealing surrounding for cultural resources, which requires a collective approach from all various stakeholder groups.

\subsection{Monolith Inscription and the People Tradition}

Connecting the data produced by this work in light of people's perceptions of when, how, and why stone circles occur around the world. Bakor stone circle is made up of individual stones from various locations that were brought together and arranged in a circular shape in their current state. The people believe that the stones were transported from Ndinton to the current location and carved by their forefathers. Nobody could give an actual date when the stone was sculpted. According to the discussions, whenever anyone died, the relatives would go and lay a stone in his remembrance. The stones are considered ancestral representatives.

The inscription on the stone indicates that the ancestors of this area had advanced technology that allowed them to interact via the use of marks. It also demonstrates that the people used an ancient writing system known as Nsibidi. Based on carbon dating, it is possible to conclude that nsibidi writing precedes the advanced form of writing. The religious significance of the stone circles stems from their use as a village meeting place. They also presume that the stones have mystical powers and are objects of reverence, which may explain why religious rites sacrifices are performed on some of them. The Interviewee interpreted the inscriptions on the stones. For every stone has a special significance as a result of the inscription on it Four (4) of the stones bear the nsibidi sign, the first of which depicts a woman in a calorie-dense room. The second sign depicts a woman in mourning after the death of her husband. A wild mark is also present. There is a tatu mark depicting a lady with a twin, as well as a cross sign, which means the entire world has four arms and is united.

Another stone is important because some rites are performed on it to entice the forefather before the "new yam festival." The stone is made up of triangular squares. The latter portrays society's four age gatherings. The two triangular squares represent the two groups of warriors who carry elephant tusk-Nkpangang and Arobe. Some show peace signs and other fertility. Another paramount is the one that has a star sign which means the man has the ability to see into the future (a visionary $\}$.

The culture of Bakor is embedded in their ways of life cultural innovation in Bakor include the uses of Nsibidi writing, Ekpe fraternity, and cultural festival in different communities. Nsibidi writing Among Ejagham people, nsibidi is one of the social and cultural developments, the evolution of nsibidi writing which has survived among secret societies 
especially the leopard society (mgbe), where it is the common means of communication (Chris 2013).

An interview with one of the museum's attendances in Alok community reveal that nsibidi sign is the form of writing in the picture, verbal and nonverbal forms of communication, he also said nsibidi sign is not just writing scrip but a language spoken with body movement, eye contact drawing lines on the ground with toes and whistling. Also, it is a sign given by families' members in form of identification or identity some families may have circle signs and other star signs on their bodies. This sign can also be seen in Fulani, Idoma, Igalla, and Nupe in Kogi State, as well as the Yoruba's, the sign, depicts the family you belong or come from. (Ojong 2008) has compared the Ejagham nsibidi to Egyptians hieroglyphics. Egyptian hieroglyphic is a system that employs characters in the form of pictures. He asserts nsibidi includes the whole range of verbal and non-verbal sign systems, including body movement, eye language, drawing on the air or ground with the feet, and many more.

The symbols are several centuries old. The symbol is said to have appeared on excavated pottery as well as ceramic tools and headrests from the Calabar region (Slogar, $2005 \& 7$ in Chris 2013). Nsibidi has a wide Vocabulary of signs usually inscribed on calabashes, wall design, brass wear, bronze, textile, wooden sculptures, masquerade costumes, swords, tattoos, building, and human skin. Below are some examples of nsibidi recorded by Macgregor (1909) and Elphinstone Dayrell (1910 and 1911) in the Journal of the Royal Anthropological Institute of Great Britain and Ireland and Man. Both of them recorded symbols from a variety of locations around the Cross River, and especially the Ikom district in what is now Cross River State. Both of the writers used informants to retrieve nsibidi that were regarded as secret and visited several Cross River communities

\subsection{To Examine Monoliths in Ogoja and Ikom Local Government Area}

Monoliths are found in Ogoja and Ikom Local government, the Area is made up of six clans the two local governments are also called Bakor's, those villages where the stones can be found include Alok, Emangabe, Nta, Nselle, Abamyom, Nde, Ekajuk, and Nkirigom. The monoliths are identified in thirty-two (32) sites. Allison in his study identified two hundred and ninety-five stones in the midst of other small-shaped stones of ellipse soil and cylindrical forms in Nta, Nselle, Abamyom, and Nnam of the region (Allison 1986). Presently one hundred and eight nine (187) monoliths were discovered and recorded in ten different locations and sites and were studied.

Table 2. Villages with Number of Monoliths

\begin{tabular}{|l|l|l|}
\hline S/N & Villages & No of stones identified \\
\hline 1 & Alok & 33 \\
\hline 2 & Emangabe & 17 \\
\hline 3 & Ntolish & 16 \\
\hline 4 & Edankono & 8 \\
\hline 5 & Nlu & 14 \\
\hline 6 & Agba & 26 \\
\hline 7 & Nkirigom & 27 \\
\hline 8 & Ntol & 30 \\
\hline 9 & Nselle & 7 \\
\hline 10 & Nebrokpa & 10 \\
\hline
\end{tabular}

Source: Fieldwork (2019) 
This show that the total number of monoliths per site, Alok has 33, Emangabe 17, Ntolish 16, Edankono 8, Nlun 14, Agba 26, Nkirigom 27, Ntol 30, Nselle 7, Nebrokpa 10 all in a semi-circle and circular form of which some are standing others are lying.

\subsection{Socio - Cultural and Religious Beliefs Associated with Monoliths and Tourism Development}

One of the community leaders said the stones circle was used as a place of sacrifice and community meeting. Another said in a different community that the stones were arranged in circles and used as a playground and community centers. While some assert that the stone was created as a memorial of departed heroes or beloved family members it was also believed that each monolith and stone represents an ancestor (or each family in a community has a representative stone)

The respondent ascribed supernatural powers to the stones. It is a belief among the people that, the face of each Akwanshi represents one of their ancestors who they do not know his name. Their forebears revered these stones and made human sacrifices to them. During some important annual festivals, these stones are usually decorated with chalk and palm leaves. The annual sacrifice of "pounded yam and palm oil" is made on the paramount stones. Some of the stones are dedicated to different gods: The gods of harvest, the god of fertility, and the god of war.

\subsection{The Contributions of Ogoja and Ikom Monoliths to Tourism Development in Cross River State}

The studies reveal that when the community recognized that tourism can change economic, environmental, social, and cultural dimensions in the local community they started gathering the carved stone in a semi-circle. The participation of the local community is a driving force for change and a catalyst for development. As noted by Telfer \& sharply (2007) local community can provide a wide range of perspectives on tourism development. The hosts' communities assert that if the monolith is developed it will increase the livelihood of the communities, create employment and generate income Tourism has become the major source of economic diversification for Nigeria allowing new employment and income-earning opportunities. Ayeni and Ebolioh (2012 in Chris 2013) noted that the developing countries account for a higher proportion of global tourism and that developing countries are beginning to take advantage of the huge opportunities offered by tourism. However, tourism does not have some advantage over other sectors for delivering pro-poor growth (Ashely \& Godwin 2001).

Most Africa countries like Kenya, Egypt, and South Africa have accorded tourism development a priority position in their natural economic planning and earned much of their national income from tourism (Aliyu 2013). Nigeria has huge tourism potentials especially its natural and diversified landscape but lacks effective tourism supporting and enhancing infrastructure. It is based on this need to diversify the economy that preservation and conservation of our cultural and historical heritage and resources become a more pressing and urgent necessity. The heritage resources are irreplaceable and priceless possession that differentiated people from other. Monoliths are also regarded as cultural heritage resources of a given people that if properly developed, will generate huge income to the state and the local populace. 


\subsection{To Examine the Management Structures That Guarantee the Continued Survival of These Monoliths}

According to the curator and museum attendance, Mr. Keke points out the fact that there are eight museum staff attendances employed by National Commission for Museum and Monuments (NCMM) that also protect and preserve the carved stones, they're also clean and maintain all the sites as well as protect them from vandalism, bush burning, stealing and human activities such as farming within and around the parameters. Looking at the situation of the museum and the heritage resource site the researcher advice that the stakeholders such as the community leaders, chiefs, and youth should form a union that would also help in protecting and preserving their heritage resources, they should also be the access road to some sites that are in the remote area for tourist to be able to access them is essential. Hence for our heritage resource to be sustainable, depending upon the maintenance, protection, and preservation of the healthy and attractive environment of those sites is a collective effort.

\section{Conclusion}

From the finding of this study, however, it can be deduced that it is possible to develop Bakor monoliths site into tourism (cultural) if properly manage and taking into consideration the appropriate step by step mentioned in the earlier part of the work to positively influence the attitude of the host communities and involved them in any planning process. It is believed that if host communities are properly involved in the management of monoliths and also avail the opportunity to contribute their quota in the planning process would boost tourism in Cross River North and Central to place the state as the number one tourist center when it comes to cultural tourism in supporting the vision of the then governor Donald Duke to promote tourism as one of the pillars of the state economy, which the administration sensitized the resident of the state on the efficacy of tourism as economy drive and provide tourism legislation (Esu et al., 2012). It is assumed that lack of information about stone circle and monoliths have an effect on the tourism of the state. If the monolith sites are well developed into tourist attractions the demand for local souvenirs like baskets, cane chairs, and mats will increase tremendously and boost the local economy. In the same vain the development of tourism in all aspects and cultural tourism, in particular, have much time led to the provision and improvement in rural infrastructural facilities include but not limited to water, electricity supply, local airstrip as well as accessibility. As such local communities can benefit from this infrastructure where the sites are located. If the above-mentioned facilities are provided by the government, destination management, private sectors as well as tour operators and other agencies for the comfort of the tourists. The local communities at the same time can make use of these facilities

There are tourist facilities that can cater to the need of tourists such as hotels, restaurants, that the tourists who wish to engage in overnight stayed, also found in the localities are markets, health centers, most of the sites are close to the road can be accessed by motorcycle or by foot. For tourism to boost, there need for proper development of all the sites. Monoliths are seen as an identity of the people. Some stones there is evidence of animals blood on it, show that scarifies are been carried out which the communities called feeding of the ancestor which is done annually between 12-14 September, the items for the scarified include yams, local salt, palm wine, a lap of deer and electric fish. Also, painting of the stones is done as well which there worshipped as the relic of the past deities. All these are done in honor of the monoliths items used for painting include can wood, calm lotion, yellow, blue, green, white, and red chalk, the yellow paint depict victory, blue for fertility, green for agriculture, white for peace, and red for war. 
Sad to say that the locations of some sites are still at risk since there has little or no protection. Traditional and modern methods were used in management practices of the monoliths site. The traditional method was useful as effective as the modern method. Both methods works hand in hand to ensure that the sites are protected and conserved. More so there are some challenges as regards the conservation of the stones in the case where a lot of monoliths have been defacing with no inscription on them in different sites due to neglect by the appropriate bodies

Finally, the communities should involve themselves in protecting their heritage which was passed onto them from the destruction of fire, stealing, decoloration as well as cracking. Hence museums should be built so as to keep proper and accurate records for ease of reference materials. The study concluded that most of the identified cultural resources have faced many challenges, therefore conscious efforts toward the management, preservation, and protection of these cultural heritages become imperative. Hence the need for sustainable cultural tourism growth and development lays upon the maintenance of the sites to be attractive to visitors and tourists generally.

\section{References}

Acholonu, C. (2013). Catherine Acholonu replies Helen Vesperini's Ikom monoliths, Nigeria's answer to stonehenge. Retrieved from Junglejournalist.wordpress.com/2013

/02/06/Catherine-Acholonu-replies-Helen-vesperinis-on-ikom-monoliths-Nigeria-answer- toStonehenge- Accessed on 12th January, 2018.

Adekoya, A. (2005). Ikom monoliths to change status of Cross River tourism for development.

Retrieved from http://www.megalithic.co.ukarticle.php Accessed on the 12th July 2018.

Agashi, V. (2017). Heritage resources in Ogoja unpublished PGD Thesis, University of Nigeria Nsukka.

Akpang, E.C. (2014). Beyond anthropological and associational discourse- interrogating the minimalism of Ikom monoliths as a concept and found object art. Global Journal of Arts, Humanities and Social Sciences, Vol. 2. No. 1, pp. 67-84.

Akpang, C. E. (2013). Found object, recycled art, readymade or junk art? ambiguity in modern African art. Arts and Design Studies, 12(1), 41-48.

Akpang, C. E. (2013). Traditionalism in contemporary art: re-contextualizing African ideographs through hybrid aesthetics. Arts and Design Studies, 11, 25-36.

Allison, P. (1967). Cross River State monoliths. Lagos: Department of antiquities, Federal Republic of Nigeria.

Allison, P. (1969). Cross River monoliths. department of the antiquities federal republic of Nigeria.

Amaratunga, R.G., Baldry, D.,Sarshar,m., \& Newton, D. (2002). Qualitative and quantitative research in the in build environment. application of mixed research approach. Work Study

Renamed International Journal of Productivity and Performance Management 51(1) 1731.

Aruku M, I (2000). The Ekajuk Culture, Calabar parfelly prianters.

Iwake (2005). Tourism potentials of obosi in Idemili North Local Government Area, Anambra State. unpublished B.A. project, Department of Archaeology and Tourism, University of Nigeria, Nsukka.

Bill, D. (2018). "'Black panther': how Wakanda Got a written language | IndieWire". cite web requires | website= (help). Access 9th August, 2018.

Bowen G (2009) Document analysis as a qualitative research method. Qualitative Research Journal Vol. 9 No. 22 Pp 27-40.

Cooper, C. Fletcher, I. Gilbert, D. \& Wanhill, S (1999). Tourism principle and practice. second 
edition. Harlow, Longman.

Christopher, D. A (2013 ). Identifying heritage resources in Ogoja unpublished master thesis university of Nigeria, Nsukka..

Dayrell, E. (1910). Some Nsibidi sign Man. the royal anthropological institute of Great Britain and Ireland. 10: 113-114. doi:10.2307/2787339. JSTOR 2787339.

De Jonge, R. M. (2010). The Ikom monoliths and the flood.

Retrieved from http://www.barry.warmkessel.com/IKOM-4.html. Access on the 4th of May 2018

Diminiyi, F,E (1995). The Bakor traditional new Yam festival: its cultural and economic implication on Ekajuk clan: Unpublished NCE Project, Department of History and Social Studies. Cross River College of Education, Akamkpa.

Egede, E, E (1988). History of Bakor, Calabar: Macky environs publishers.

Esu, B.B. \& Ukata (2012). Enhancing the tourism value of Cross River State monoliths and stone circle through geo mapping and ethnography. Journal of Hospitality Manage and Tourism. Vol. 3 No.6 Pp106-116.

Halloway, J.C (2006). The business of tourism. England Pearson Education ltd Edinburgh hate. Heritage of Japan (2012). Discovering the historical context and culture of the people of Japan.

Retrieved from http; heritageofjapan.wordpress.com /pacing-the Paleolithic-path/stone-ageaccess. Accessed the 20th May 2019, 10: 40.

International Council of Museums, (1982) and Association of European Open-air Museums. Principles for the Creation and Operation of Open-Air Museums. Association of European Open-Air Museums.

Isichei, E. A. (1997). A History of African societies to 1870: Cambridge university Press. p. 357. ISBN 0-521-45599-5.

Isichei, E. A. (1870). A History of African societies. Cambridge: Cambridge University Press, 1997.

Ivor, M. \& Abu, E. (2015). Cross River monoliths in critical danger of total destruction: department of history and international studies, university of Calabar, Cross River State.

Knight C (2012). The mystery of the megalithic yard revealed: How to create the prehistoric measurement unit for yourself. Retrieved from Http://ancientwisdom.co.uk/megalithicyard.htm\#thom. Accessed the May 2018, 12.40.

Macgregor, J. K (1909). "Some notes on nsibidi". Journal of the royal anthropological institute. royal anthropological institute of Great Britain and Ireland. 39: 209-219. doi:10.2307/2843292. JSTOR 2843292.

Miller, H. \& Flugel, M (1999). Tourism and okologies, forsdungsiasstitact fvi freigeit and tourismus (FIF) an der university at Bern, Bern, Pp310.

Murphy, A (1983). Ogoja yesterday, today and tomorrow. Calabar: Igoli Ushie Prianter

Nash, M. (1963). "Introduction approaches to the study of economic growth". Journal of social Science vol. 29, No. 1.

Nkombe W.M. (2006). Ekajuk history and aspect of culture. Ogoja pafelly printing press. Okpoko, A.I. \& Okpoko, P.U. (2002).Tourism in Nigeria. Nsukka: Afro-Orbis publishing co.Ltd.

Okpoko, A.I \& Ezeadichie E.U (2002). Cultural heritage and sustainable development in Africa. Nsukka. Journal of humanity No. 12, Pp 1-8.

Rentzhog, S. (2007). Open Air Museums: The History and Future of a Visionary Idea. Sweden: Carlssons.

Slogar, Christopher (2007). Early ceramics from Calabar, Nigeria: towards a history of nsibidi. African arts. University of California. 40 (1):1829. doi:10.1162/afar2007.40.

Slogar, Christopher (2005). Iconography and continuity in West Africa: Calabar terracottas and 
the arts of the Cross River region of Nigeria/Cameroon. Eyo, Ekpo (ed.). University of Maryland. pp. 58-115.

Telfer, D.J, Sharpley, R. (2007). Tourism and development in developing world: Routledge. P 280.

Thom, A. (1967). Megalithic sites in Britain. Retrieved from http:/ /ancient-wisdom.co.uk/megalithicyard.htm\#thom. Access on the 20th of May 2012.

Thom, A. (1978). Megalithic remains in Britain and Brittany clarendo, Oxford: university Press.

UNESCO (2007). Alok Ikom monoliths UNESCO online retrieved from http://whc.unesco.org/tentativelist/5173. Access on 20th of march, 2019.

Enemuo, Ogechi (2009). Potential of cultural resources in tourism development of Abia State, $\mathrm{Ph} . \mathrm{D}$ thesis department archaeology and tourism, university of Nigeria, Nsukka.

Vesperini, H. (2007). Nigeria's answer to stonehenge: the Ikom monoliths. [Online] AFP. Availableat:http://www.google.com/hostednews/afp/article/alegm\%iogc4zutlrgqyevoqjfp cmwar Accessed on 10th June, 2019.

Wall, G. \& Matheison, H. (2006). Tourism change and opportunities. England: Pearson education Ltd. Pp 30.

Witt, D. (2012). Professor Alexander Thom and megalith astronomy: a revival of interest, SOUE news, http://www.soue.org.uk/souenews/issue8/thom.html. [Accessed the 20th January 20119, 11:20].

Wisker, G. (2009). The undergraduate research handbook. New York. Balgrave Macmillian.

World Monoliths Fund (2008). Ikom monoliths of Cross River State. Retrieved from www.wmf.org/project/ikom. monoliths-crossriver-state (Access the 05th January 2019).

Wikipedia (2018). Stone circle homepage-ancient wisdom: online guide to prehistory. Retrieved from http://www.ancient-wisdom.co.uk/stonecircle.html. (Access 20th December 2018, 09:10) 